\title{
Venezuela: Libraries and Librarianship
}

\author{
Juan D. Machin-Mastromatteo \\ Renny Granda
}

This chapter was originally published as:

Machin-Mastromatteo, J.D. and Granda, R. (2017). Venezuela: Libraries and librarianship. In J. McDonald y M. Levine-Clark (Eds.). Encyclopedia of Library and Information Sciences (4th. ed.). (Vol. VII). (pp. 4886-4895). Boca Raton: CRC Press, Taylor \& Francis.

https://www.taylorfrancis.com/books/e/9781315116143/chapters/10.1081/E-ELIS4-120052476

\begin{abstract}
This article presents a general, brief, and not exhaustive overview on the origin, development, and the crises of Venezuelan libraries and librarianship. The first section offers an historical background on the first Venezuelan libraries, highlighting the origin of the National Library, together with some of the most important characters of this early history. Moreover, it narrates milestones such as the first Law of Libraries of the country, the celebration of librarian's day, and Caracas Declaration. The second part briefly presents some current types and examples of Venezuelan libraries, such as academic, public, special, digital, and repositories. The third section mentions the development of Venezuelan librarianship, the related professional degree and professional education, including the main schools, programs and curricula. The fourth part summarizes the current crisis faced by libraries and the profession itself. Finally, some brief comments are offered as a conclusion.
\end{abstract}

Keywords: Venezuela, libraries, librarianship, history, curriculum, current challenges.

The university cannot be neutral in the historical debate between democracy and dictatorship. Rómulo Betancourt (1959).

A National Information Policy has more possibilities of receiving significant government attention if it were supported by information professionals. Iraset Páez Urdaneta, In Information for the development of Latin America (1990).

Manuel Segundo Sánchez showed, in his patient and quiet labor, that there was a liberating force of the spirit, that there was an escape and an alibi to arm the resistance, which was no other tan mankind's culture, in front of which dictators and warlords in power would never understand their unassailable argument. Karl Krispin (2007).

\section{Introduction}

The topic of libraries and librarianship in Venezuela is challenging. Over the last years, this sector has had the same results as any aspect of national life: fragmented, dispersed, confused, hermetic, and uncertain. In this Latin American country, librarianship is an undervalued profession; it is not taken into account, even by the academia. Only two universities offer undergraduate programs on librarianship, and they keep a technical paradigm tied to archival science. In general, library infrastructure is scarce given the national population of over 30 million inhabitants. The development of school libraries is practically inexistent, the National System of Public Libraries (NSPL) was established between 1970 and 1980, and the base of the pyramid is comprised by the academic libraries, which are located throughout the main cities of the country. Some special and institutional libraries are noteworthy, but they are isolated cases. The National Library (NL) is the main library institution in the country, public policies of the sector and the planning of the NSPL stem from it. However, this institutional figure has not being enough to carry out large projects and a responsible and stable professional scholarship. Within a complex political, social, economic and cultural context, Venezuelan libraries claim to be vindicated.

\section{Historical background}

Historians set the arrival of books to Venezuela between the $16^{\text {th }}$ and $17^{\text {th }}$ centuries. From 1600 , the presence of books starts to be notorious in colonial time cities [1]. Books arriving from Spain made possible to start developing the first libraries with these manuscripts or printed books, from approximates of 25 to 500 volumes, and in no way they represented the ideal institutions for the custody, preservation, and classification of collections, which started to appear from the $19^{\text {th }}$ century [1]. This section summarizes the first Venezuelan libraries, the first printed publications, the origin of the $\mathrm{NL}$, as well as the most important figures of this early stage of Venezuelan libraries and librarianship, such as the first bibliographers and the leading roles of Rómulo and Virginia Betancourt. Moreover, some notable developments are presented, such as the first and only law of libraries in the country, 
the events leading to the commemoration of the librarian and archivist day, and the Caracas Declaration.

\section{A. First steps and the establishing of the National Library}

The first known colonial library belonged to the Convent of Our Lady of Salceda in St. Anne of Coro, it was established by the end of the $16^{\text {th }}$ century, and according to chroniclers, historians and librarians, it was comprised of 300 volumes which were sometimes lent to the city's inhabitants [2]. Libraries from the $17^{\text {th }}$ and $18^{\text {th }}$ century were mainly private and belonged to national aristocrats, destined to family use, as well as those belonging to the clergy [1].

In 1691, there was a notable decree by the provincial of the Franciscan order, Diego de Hoces, which indicated how convent libraries should function and it called for the appointment of a librarian to be in charge of the loan service for two hours each day and to maintain a written log for this service. This is the earliest registered presence of a librarian in Venezuela. A century later, in 1790, the first known librarian appears: Father Cristóbal de Quesada, who also taught Latin and grammar to Andrés Bello, and worked at the library of the Convent of the Mercy in Caracas [1]. At the time of the Independence $\left(19^{\text {th }}\right.$ century) there were two key moments: the first Venezuelan periodical, the weekly Gazette of Caracas, was printed in 1808; and in 1810, the first book was printed, the Manual Calendar and Universal Guide of Foreigners in Venezuela for the year of 1810. Both publications were prepared in the press owned by Gallagher and Lamb [2]. Furthermore, the idea of a new type of library which would allow readers access emerges: the public library. Its role was also intended as a tool for public instruction after the date of the Declaration of Independence, on April $19^{\text {th }} 1810$ [1]. This idea was published in a printed sheet that began to circulate by the beginning of 1811, Thinking of a public library in Caracas, signed by Juan Germán Roscio and possibly written by Francisco Javier Ustáriz [1, 2], both signatories of the Declaration of Independence. It was the first intention of a project to create a public library, which was deferred by the Independence War. Even so, during the period of the War till Death (1814), the Liberator Simón Bolívar commissioned the collecting of books and ordered the formation of a public library [2].

From 1830, the idea of creating a NL appears. Particularly in 1831, the Interior Secretary Antonio Leocadio Guzmán manifested the need of merging the convent libraries and books dispersed throughout government offices [1]. Diverse decrees with the intention of creating the NL were issued in the subsequent years, but these initiatives were not so successful. Some of such decrees were: a) by president José Antonio Páez in 1833, pointed out by some scholars as the date of the foundation of the NL [3,4]; b) by president José Tadeo Monagas in 1850; c) a decree from 1852, which also assigned a budget to the NL; d) by president Julián Castro in 1858 which appointed several directors and organizational changes; and e) by president José Ruperto Monagas, in 1869, which presented improvements for the NL in areas such as staff salary and service regulations. Finally, in 1870, it was during the government of the president Antonio Guzmán Blanco that a solid base for the functioning of the NL was established [1]. The first statistical report of the NL collection appeared in 1873, being comprised by 5.862 volumes. In 1874, Guzmán stipulated that the collections of the convent libraries were to be delivered to the Universidad Central de Venezuela (UCV), the first and largest public university. These collections were to be incorporated to the NL, which was located at the time in the university campus. In 1875, Adolfo Enrns publishes the Catalog of the Library of the University of Caracas, the first printed catalog of the NL and of Venezuelan bibliography. Ernst directed the NL from 1876 to 1889. In 1892, the library separated from the UCV and in the following year it was moved to other location through a decree by the president Joaquín Crespo [1].

At the beginning of the $20^{\text {th }}$ century, the situation of the country was critical due to the Civil War. When Juan Vicente Gómez gets into power in 1908, he decided to appoint the construction of a dedicated headquarter for the NL, so in 1910 he commissioned architect Alejandro Chataing with this construction. This new headquarter was built next to the UCV and it was inaugurated in 1911, coinciding with the commemoration of the Centennial of the Independence. In 1937, after the end of the dictatorship, a stage of modernization of the NL was started by its director Enrique Planchart. From 1950 toward the end of the $20^{\text {th }}$ century, the library had five directors; the most important of them took office in 1974 and transformed the institution into an autonomous organization, among other improvements. In 1960, the Book Bank was created as a non-profit organization and starting a new vision of library services. In 1974, Venezuela becomes the first Latin American country to have policies for the creation of a NSPL [1]. The current headquarter of the NL, designed by José Tomás Sanabria, consists of a building with a total size of 80,000 square meters, which was constructed from 1981 and began to function in 1989 [2].

\section{B. The first bibliographers}

In this brief historical journey, it is relevant to mention the first characters that conducted activities related to this discipline. In the first place, there were the fathers of Venezuelan bibliography, Arístides Rojas, Adolfo Ernst, Juan Piñango Ordoñez, Adolfo Fryndesberg, and Manuel Segundo Sánchez. The latter was a true pioneer in setting the bases of Venezuelan bibliographic research, by establishing the foundations for the development of this discipline 
in Venezuela, and from 1913 to 1920 he directed the NL. Among his most important works were: Venezuelan Bibliography (1914), which includes nearly 1500 records and until now it is considered the only work of its kind; the Venezuelan library (1917), Bibliographic yearbook (1917), which the NL took as a model from 1942 in order to systematically compile its own yearbooks; and the Bibliography of bibliographic indexes related to Venezuela (1939). He also conducted researched on the printing press in Venezuela and created the denomination of Venezuelan incunabula for every Venezuelan publication printed from 1808 (year of the first printed publication) and 1821 (Battle of Carabobo). Curiously, Walter Lichtenstein acquired the private library of Sánchez and his books ended up in universities of the United States such as Harvard, Northwestern and the University of Chicago. Finally, there is the figure of Pedro Grases, compiler of the fundamental writings of Venezuelan intellectuals and statesmen. His most important works are related with the history of the printing press in Venezuela, an inventory of printings of the period between 1808 and 1812, the trajectory of the Gazette of Caracas from 1808 to 1822, the Angostura printings of 1817-1822, the Venezuelan Constitution of 1811, his bibliographic research on various subjects and profound reflections on Venezuelan bibliographic research [5].

\section{Rómulo and Virginia Betancourt}

Rómulo Betancourt was the first president of the Venezuelan democracy (1959-1964), he belonged to the Generation of '28, a group of student leaders which organized the first popular manifestation against the dictatorship of Juan Vicente Gómez (1908-1935). Being a strong opponent of the Gómez regime, he lived a part of those years in exile. Between 1931 and 1935 he lived in Costa Rica, where he started his ideological journeys throughout Latin America. In those years, he worked at the National Library of Costa Rica, taking advantage for advancing and deepening his reading of works such as the 15 volumes of the Contemporary History of Venezuela by González Guinán, resulting in his writing of a magnificent summary [6]. Betancourt was a militant in diverse clandestine political organizations such as the Venezuelan Communist Party and the National Democratic Party. The latter was the predecessor of the political party Democratic Action (AD), founded in 1941 by Betancourt and other Venezuelan left-wing leaders. Betancourt converted a country of warlords and militaries into one of a civil society and republican institutions [7]. Because of his political views, he was eternally pursued, but despite this persecution and his strong dissident activities he never stopped reading, studying, writing, and publishing journalistic articles, booklets, and books [6]. His daughter, Virginia Betancourt will always be appreciated by the educated and democratic Venezuela for her efforts as director of the NL between 1974 and 1999, her contribution in the founding of the Book Bank in 1960, and her labor in preserving and classifying her father's personal archive [6]. During her administration of the NL, he was responsible of establishing the autonomous character of the institution, of creating the NSPL and promoting the Law of Libraries of 1977. Additionally, she encouraged professional meetings and of Latin American integration, such as the one which originated the Caracas Declaration. She also participated in the creation of the Association of Ibero-American National Libraries (ABINIA) and her labor made her worthy of the International Federation of Library Associations and Institutions (IFLA) Medal in 2005.

\section{Law of Libraries (1977)}

The National Library Autonomous Institute and Library Services (NLAILS) Law [8] created the figure of the NLAILS from the NL and was the basis for the creation of the NSPL. It was during the era of the discourses about systems, networks, and library management, besides the modernization and transformation of the NL. Legislators and leaders took the advantage of this opportunity to start building the library network throughout the country. With this Law, Venezuela stepped forward into the vanguard of the library movement in Latin America, being the third country of the region to create a Law of this kind [9], which was even considered a model for some library movements in Latin America [10].

The NLAILS Law is still in effect, as no new legislation has been passed, despite the fact that it is obsolete and it does not develop the particular area of public libraries (PL). The Law is now obsolete because it is antiquated and inadequate given the current circumstances it must govern. It was passed more than 30 years ago, when another Constitution ruled the country's destiny, thus overpassing the limits Venezuela's legal reality. The current Constitution of 1999 brought significant changes in every institutional area, mainly materialized through different legal reforms made by the new parliament and especially with legislation through presidential decrees. The NLAILS Law is a survivor of that time of major legal reforms. In consequence of the mentioned changes, this Law stopped being useful in its area of application, and nowadays it is officially mentioned exclusively when the President makes changes in the Direction of the NL.

\section{E. Librarian and Archivist's Day, one date and three motives (1982)}

The National Librarian and Archivist's Day is celebrated every July $27^{\text {th }}$. This date was chosen as the most iconic for the profession for three reasons. Firstly, on July $27^{\text {th }} 1945$ is recorded as the date of death of Manuel Segundo Sánchez. Secondly, July $27^{\text {th }} 1950$ corresponds to the graduation of the first cohort of library and archives professionals from the UCV. The third event happened on July $27^{\text {th }} 1977$ with the enactment of the NLAILS Law [8]. 
Considering these events, on July $23^{\text {rd }} 1982$ the Presidential Decree $N^{\circ} 1.564$ was published in the Official Gazette of the Republic of Venezuela ${ }^{\circ}$ 32,522, declaring July $27^{\text {th }}$ as the National Librarian and Archivist's Day. The document states:

the activities of Library and Archives professionals constitute factors of progress and development for the country, because they fulfill support to education, research, and to the development of science and technology through libraries, archives and information and documentation centers, hence it is fair to recognize their function within the Venezuelan society (p. 245827) [11].

\section{F. Caracas Declaration (1982)}

The Caracas Declaration for the Public Library as a factor of development and instrument of social change in Latin America and the Caribbean was the product of the consensus between experts from 30 countries, that was reached during the Regional Meeting on the Current State and Development Strategies for the Development Public Library Services in Latin America and the Caribbean, during October 25-29 1982. The Declaration is the first and most important technical-normative document on PL of the region because it allowed pushing the library movement in Latin America and the Caribbean (LAC). The Declaration was a regional agreement celebrated in the Venezuelan capital and supported by the United Nations Educational, Scientific and Cultural Organization (UNESCO), the Regional Center for the Promotion of the Book in Latin America and the Caribbean (CERLALC), IFLA, and the Venezuelan NLAILS. The Declaration contains the shared visions of the region's professionals at an historical moment: one which opened the door to wider views of social reality, democratic life, and regional integration. Hence, one of the first aspects it mentions is the support to the main principles stated in the UNESCO Public Library Manifesto of 1972. From these principles, the main needs of the region were compared and they were adapted to LAC reality in order to adopt them. The first part of The Declaration enumerates the eight principles for PL of the region, in order to assume the commitment toward development, democracy and social change in LAC. These principles "express the will of a library majority on what the public library should be in our countries" [12]. These are summarized as follows:

a) Ensure free access to information which must be broad, current, and representative of the sum of different thoughts, in various formats.

b) Stimulate people's participation in national life, enhancing the role of the library as facilitator of social change and participation in democratic life.

c) Promote the understanding, dissemination, and defense of national indigenous and minority culture to assert cultural identity and the recognition and respect toward other cultures.

d) Promote the formation of critical, selective and creative readers through reading, thus training each individual to play an active role in society.

e) Support lifelong learning, eradicating illiteracy and supporting services for children, teenagers, neo-readers, and disabled readers, both social and physically.

f) Serve as information and communication centers for the community.

g) Develop national library services.

h) Support an economically strong and culturally independent national and regional editorial industry. [13]

The second part refers to the basic conditions for the development of PL in LAC, conforming a vision closer and more real regarding the state of the LAC library, stating the true needs or shortcomings, mainly institutional, which prevented (and in some cases, still prevent) the improvement of services in the region. The Declaration states the need of a legal framework to regulate the functions of the PL, contemplating State obligation to offer library services, a national coordination, a system of services, normalization of technical processes, strategies to train human resources, and the sustainable endowment of services. It highlights the role of the State "regarding its functioning and development, and emphasizing the need of the libraries to be included in the development plans of each country, in pointing the State obligation to offer public library services and assigning them sufficient yearly budget for their development" (p. 17) [14]. Moreover, issues such as "to stimulate citizen participation in democratic life" (p. 16) [10], started to be taken into account.

\section{III.Venezuelan libraries}

The national library infrastructure is currently scarce, given a population of over 30 million inhabitants. Regardless, this section mentions the main libraries: academic, including university and school libraries; the dense network of public libraries and their variations; special libraries supporting the labor of both the private and public sectors; institutional and governmental libraries, and lastly some experiences in digital libraries and repositories.

\section{A. Academic libraries}

Venezuelan academic libraries include university and school libraries. In public and private universities there are libraries which fundamentally support professional development and research. The most relevant from public universities are those of: Universidad Central de Venezuela, Universidad Simón 
Bolívar, Universidad de Los Andes, Universidad de Carabobo, Universidad del Zulia, Universidad de Oriente, and Universidad Nacional Abierta. The most relevant from private universities are those of: Universidad Católica Andrés Bello, Universidad Metropolitana, and Universidad Santa María. The main national universities also count with specialized academic libraries according to the Faculty or field of knowledge to which they dedicate. School libraries can be found in private institutions but especially in public schools. The responsibility of the State in the conformation of a public school library system rests in the Ministry of Education. In the mid-1980s there were nearly 1,700 school libraries dependent from the mentioned governmental office $[1]$.

\section{B. Public libraries}

The NLAILS is the governing body of the NSPL and it was inspired by both the UNESCO Public Library Manifesto and the Caracas Declaration [4]. The system is comprised by 727 libraries nationwide, organized in 24 state library networks with a total capacity for approximately 38,229 readers, 3,687 of them are located in the capital city of Caracas [15]. Despite these figures, some of its weaknesses are related with the lack of clear policies, technological infrastructure and an inadequate library staff selection, which in general is neither professional nor trained for such functions [4]. Regarding statistics, $88 \%$ of PL users are students, with an average age of 20 years old, and $71 \%$ percent of them study in public institutions. Only $12 \%$ percent of the total users do not study and their average age is 37 years old, from this percentage $75 \%$ of them are employed [15]. Part of the explanation behind these figures is that in many cases PL fulfill the roles or alleviate the lack of school libraries in many sectors throughout the country.

Among the PL, one of the most emblematic is the Book Bank because it was established in 1960, before the NLAILS Law was even drafted, but still it started to provide the basic framework to start developing a network of school and public libraries, firstly in Caracas and then in other regions of the country. The Book Bank is the "depositary of a valuable collection comprised by books for children and teenagers, specialized literature on these literary genres, documental records, periodicals, and texts related to the book and reading promotion.” (p. 25) [3]. The Book Bank researches, experiments, innovates and proposes guidelines for reading promotion, and also carries out diverse cultural activities that do not necessarily related to reading.

\section{Special libraries}

The Marcel Roche Library of the Venezuelan Institute of Scientific Research (IVIC) might be the most relevant special library of the country and because it is subordinated to the Ministry of Science, Technology and Innovation, it is one of the few libraries that can afford and acquire academic databases and scientific journals, given the currency exchange control imposed by the government since 2003. Other notable special libraries are those from each of the National Academies: Language, History, Medicine, Political, Economic, and Social Sciences; Physical, Natural and Mathematical Sciences; as well as the Ernesto Peltzer Library of the Central Bank; the libraries of the Supreme Court of Justice, National Assembly, Attorney General; those in the museums of Natural Sciences, Fine Arts, and Comtemporary Arts; the library of the Rómulo Gallegos Center of Latin-American Stydues; and those within some foundations, such as the Rojas Astudillo, Pedro Manuel Arcaya, John Boulton, Vicente Lecuna, Humboldt, La Salle, Centro Venezolano Americano, among many others [1].

\section{Digital libraries and repositories}

Regarding digital libraries, the Venezuelan experiences have been incipient. The closest related cases are repertories of specialized information, such as the Scientific, Humanistic and Technological Information System of the UCV, university digital journals and some repositories such as: National Repository of Open Source Software, Intellectual Production Repository Universidad Centrocidental Lisandro Alvarado, SABER UCV, SABER Universidad de los Andes (ULA), Institutional Repository Universidad de Oriente, Institutional Repository Universidad Pedagógica Experimental Libertador, and Intellectual Production Universidad Simón Bolivar. Finally, there is the repository Metadatum, which aims to group all the academic repositories of the country that are using the OAI-PMH protocol, and to serve as a metasearch engine.

Although there are many repositories in the country's main universities, the first and only institutional open access mandate dates from 2009 and corresponds to the ULA. This consists in preserving the following documents in institutional repositories: a) theses, b) research products funded by the Scientific, Humanistic and Technological Development Council, and c) all University publications [16]. Despite this scenario, it is important to point out that Venezuela has the sixth place in number of publications indexed in the Network of Scientific Journals from Latin America and the Caribbean, Spain and Portugal (Redalyc), with a total of 54 quality scientific journals, in open access [17].

\section{IV.Venezuelan librarianship}


There are two Venezuelan traditional Library schools, the Schools of Libraries and Archives of the Universidad Central de Venezuela (EBA-UCV) and its counterpart in the Universidad del Zulia (EBA-LUZ). The UCV is located in Caracas, the capital city. It was founded in 1721 and it is among the oldest universities in the occidental hemisphere. This university has been the alma mater of many notable Venezuelan scientists, humanists, intellectuals, and presidents. Its current location, the University City of Caracas was built between 1940 and 1960, it was designed by Carlos Raúl Villanueva, with the collaborations of avant-garde artists from the era, and in 2000 it was declared a World Heritage Site by the UNESCO. The EBA-UCV was founded in 1948 and it offers two five-year bachelor programs, one in Library Science and the other in Archival Science. It also offers two master programs: Management of Information Networks and Information and Communication for Development.

The EBA-LUZ was created in 1962 and it offers the same bachelor programs together with a master in Information Sciences. Other universities with more recent academic options are the Universidad de Carabobo, centering on documental certification courses and bachelors; the Universidad Católica Andrés Bello, with a master on Information Systems and the Universidad Yacambú, with a bachelor in Information and Documentation. Sadly, there are no doctoral options in the field, resulting in a few doctors with LIS PhDs obtained in other countries and the majority of doctors with a LIS background have obtained PhDs in Education, Sociology, Social Sciences, among other disciplines. For the year 2001, there were a total of 3490 LIS professionals registered in the country, nearly 1900 of them were women [18].

\section{A. Origin of the professional degree (1950)}

The period between February and July 1950, saw the definition of the university degree conferred upon the first library and archives professionals of the country. The first director of the EBA-UCV, José Fabbiani Ruiz, manifested his unrest on the matter on February $4^{\text {th }}$, proposing the title of catalogerlibrarian. Just a month before the graduation of the first cohort of students, in the Assembly on June $26^{\text {th }}$, Fabbiani argued that even if the previously mentioned title was approved in a previous session, the students, director and teachers of the School thought that the alternative title of librarianship technician was more adequate. That was mainly because the title of catalogers would presumably prevent them from directing a library, being necessary to obtain a more general and positive title, one that would be a promise and not a menace, according to Fabbiani. The ensuing discussion had interventions from professors Acosta Saignes, Olivares Figueroa, Oliver, Rosenblat, Granell, the Faculty Dean Casanovas and Fabbiani himself. Finally, several titles were proposed: library technician, library technique graduate, library assistant, library auxiliary, and librarianship technician. After some deliberations a voting took place, the winning alternative was the one proposed by the School. Hence, on July $27^{\text {th }} 1950$ the first Librarianship Technicians of the country had their graduation [19].

\section{B. Professional education}

Venezuelan librarianship professional formation was in part caused and inspired by the seminal speech that José Ortega y Gasset delivered in the Second IFLA International Congress, in the Universidad de Madrid, on May $20^{\text {th }} 1935$. The mentioned discourse was published as the book titled Librarian's Mission, which was the way these ideas were disseminated in Venezuela, before there were professional education schools. The mentioned ideas made people start to realize that the profession was a collective need and it was socially indispensable, thus making vital to professionalize a traditionally empirical occupation [20]. Some of Ortega y Gasset's ideas that are inherent to the essence of Venezuelan information professionals and the early curriculum designs are: a) a concern with enabling access to information as a human right, either for the purpose of scientific and financial advancement as well as for communication and recreation; and b) the idea that the right to information is the means that ensures the scientific, humanistic, technological and social progress of the country and the world [20].

Moreover, from the cited ideas, library and archives schools are responsible of developing professionals who may contribute in part to their profession, through teaching and research; and also to society, being aware of social, financial and scientific development at a global level and to answer any need of information, science and culture that society may have. The national professional training has seven bases that were stated from the beginning as different skills: basic, administrative, technical processing, information sources, documentation and information, research, and understanding of human nature [20]. These bases have been kept until today, adding additional facets such as to have historical and social consciousness of the objects and areas of study, as well as topics of social relevance such as user formation, reading promotion programs, and information literacy. Moreover, there are the technological facets, of information policies and of informetrics. All these facets are not necessarily integrated in the compulsory curriculum, but they may be developed by the student through elective courses or as transversal axes in the curriculum design. Regarding their attitudes, the ideal professional must be: competent, critical, reflexive, and participant in the issues of their context. Additionally, good Venezuelan librarians are characterized for their service vocation, constancy, professionalism, their lifelong learning and for pushing to the limit the resources and possibilities at their disposal for providing their services and fulfilling their mission.

It is complicated to summarize the current state, the challenges and opportunities of Venezuelan professional training, because every institution has 
their characteristics and circumstances. In the frame of developing some contributions to the curricular change, three stages of the curricular evolution in the EBA-UCV have been defined: technical, disciplinary, and transdisciplinary; indicating that the revision and updating of the curriculum and the naming of the professional studies in the field have been deferred [21]. The transition in the EBA-LUZ has passed from a theoretical and technical formation, then reinforcing management and technological areas, and finally it has diminished the general formation, enhancing professional and research courses $[21,22]$. In both cases, the main considerations behind the initiatives of curricular change have been driven by academic and employment dynamics, both nationally and internationally, which are also what informs the construction of the professional profile. In the country, there have been curricular evaluations in the EBA-LUZ [22] as well as comparative evaluations between the Venezuelan curricula. The latter have set the bases for developing guidelines and methodologies to guarantee aspects such as: quality assurance, pertinence of formation, the degree to which formation answers the needs of the discipline and society, the possibility of national and international accreditation, and internationalization [23]. Regarding the comparative study of Venezuelan curricula, it turns out that both are academicist, humanistic, and sociological, but the elements to revise in national curriculum design are: teleological, axiological, transdisciplinar, cooperation and interchange fundaments; as well as to develop market studies to achieve an empirical and common grounding for curricula design, being aware of the local and global relationship, to strengthen the construction of a pedagogical theory, and encourage the configuration of knowledge, learning and research networks [24]. Finally, the need of introducing the competency-based curriculum has been stressed, and it is something that the EBA-LUZ has already tried [25].

Apart from the cited experiences that improve the curricula, some authors highlight the dubious need of framing the curriculum to the initiatives of the current Venezuelan government administration (1999-2014), thus presenting the Information Sciences Formation Program [26]. This program, given its definition and except for its ideological fixation, results redundant when considering the already established learning options, as it indicates that it is innovative simply because it seeks to overcome anachronisms that sadly are grounded in the general perception that people has about the information professional but that the mentioned traditional university formation already takes into account. These perceptions are: the exclusive role of a custodian, to grant access to information to the communities, and to improve means and devices for information handling. In conclusion, this tends to erroneously insinuate that the established formation programs do not take into account the needs of the society as well as those from public and private institutions.

\section{Current state}

Venezuelan situation has been becoming more complicated during the last 22 years, with events that have resulted in the current and never before seen financial, political and social crisis, such as the Black Friday, the Caracazo, failed coups d'état, trials to government officers for corruption charges, a new Constitution, devaluations and currency exchange controls, a new political class in power, the enterprise and oil strikes, instability, an unsafe country, as well as polarization and confrontation. It is only to be expected that Venezuelan libraries and librarianship are outside of these issues and like it has happened with other sectors, they have suffered the ideological and polarizing onslaughts that have been occurring during current government administration (1999-2014).

\section{A. Libraries and their public}

For 1999, Venezuela had already shown a high literacy rate, with approximately $92.3 \%$ of the population of over 15 years [27]. However it seems that in Venezuela, the discussions on libraries have been put aside, because of the country's situation, of society and librarians themselves, of the development of Information and Communication Technologies (ICTs) or because Internet has displaced reference librarians and now everyone searches independently for information, for better or worse. Moreover, libraries have not been given their place, importance and the fundamental value they deserve, thus there is a general lack of interest in them. The figures confirm it, $80 \%$ of the population recognizes that they do not go to a library, barely a 9.1\% visits a public library, and an ephemeral $1.2 \%$ goes to the NL for information and education needs [28]. Officially, it has been reported as a significant achievement that in 2012 the NL had attended more than 11 million users (p. 414) [29]. Furthermore, the paradox of a raising number of readers but not of books sold is starting to be envisaged. The main cause of this phenomenon can be found in the infamous currency exchange control, which is described in the following section.

\section{B. Financial issues}

In order to discuss the financial issues of Venezuela, it is necessary to take into account the presence of a set of complex rules that have regulated a governmental currency exchange control during the past 12 years. These rules have contributed to a massive inflation, costs speculation, and innumerable challenges for any person or institution intending to travel or acquire imported products or services. This currency control was established in 2003, it is based on official exchange rates for US Dollars (USD) and Euros, and it is still in place with complementary or alternative currency 
exchange systems. These schemes complicate the financial situation, because they started with an exchange rate of 1.60 Bolívares Fuertes (BsF) for each USD, then BsF 1.92/USD in 2004, and BsF 6.30/USD in 2013.

Today, the currency control is based on a new scheme of three values, one fixed to 6.30/USD for 'prioritary' sectors and the other two are 'complementary': the first starts at BsF 11.36/USD, but with high fluctuations, and the second is an alternative system that seeks to eliminate the alternative black market, by fluctuating according to supply and demand, and starting at BsF 51.86/USD. This control, together with the currency reconversion of 2008, which eliminated 3 zeroes to the national currency and the calculation of the National Budget according to the prizes of the oil barrel, have resulted in the creation of development funds that are discretionally managed by the government and have casted serious doubts about their transparency. Academic libraries have felt the most direct impact of the currency exchange control, because for them it is very hard, if not impossible, to receive the foreign currency needed to subscribe academic databases and import library materials that are not manufactured in the country. This makes the IVIC library, because its subordination to the State, one of the few libraries of the country that can currently count with these resources.

The current main economic activity of the country is the oil exploitation, between 2000 and 2008 there was a spectacular rise in oil barrel prizes, from 20 to more than a 100 USD. Despite its condition of being a single product economy, Venezuela has been privileged because of the volatility of prizes and the immediate liquidity of oil sales in the international market. According to the National Institute of Statistics, between 2003 and 2012 , the government made a social inversion (SI) of 772,000 million USD, mainly through the so-called "Social Missions". The SI for the period 1999-2011 represented around 60\% of the State's income [30]. Moreover, between 2008 and 2012, the State oil company Petróleos de Venezuela (PDVSA) received a total income of 520,000 million USD (p. 156) [31]. It has been calculated that the revenue for 2013 was between 82,000 and 85,000 million USD [32].

Between 2004 and 2009, Venezuelan SI was directed firstly toward education, then social security, health, housing and services, social development and participation [33]. However, the investments made in culture, communication, and science and technology occupy a precarious space in the assignment of public expenditures. Considering the magnitude of the SI, it is valid to ask how much have been invested in Venezuelan libraries. Sadly, it is difficult to offer a detailed scenario with the scarce statistical data offered by the NLAILS, moreover, on its website there is no data available on any library indicator. Furthermore, the available statistics go only as far as 2005, and except for the Cultural Statistical Yearbook, 1990-2003: Venezuelan book's and libraries' numbers [15]; one copy of the 2007 Statistical Yearbook of the NL and the Annual Reports and Accounts of the Ministry of Culture (MCMPPC) [34], there are not enough pertinent data sources. Through the study of the different editions of this last source it is possible to calculate that the total inversion dedicated to the NLAILS and hence to our libraries between 2005 and 2013 was of 1,169.9 million BsF, or 315.9 million USD. During this period, NLAILS has directed its plans through projects which essentially reiterate every year the reinforcement and push of the NLAILS and the NSPL. This indicates that this goal has not being achieved or not completely. It also means that the majority of the resources should have been directed to invest and develop the NSPL [34]. In order to put the previously mentioned amount in perspective, we can take into account that PDVSA's income between 2008 and 2012 were over 520,000 million USD. Then, the resources transferred to the NLAILS in the same period were of 186.4 million USD. This means that the SI directed to the PL sector in Venezuela represents $0.03 \%$ of the total revenue generated by the sales of oil. Thus, a great deal of the issues of the NSPL is originated by budget problems.

The obstacles highlighted in NLAILS reports during the execution of the mentioned projects are: insufficiency of financial resources, insufficient assignation provided by the Law of Budget, suspension of the Information System Northwestern Online Total Integrated System (NOTIS), noncompliance of the Law of Legal Deposit, cuts in the planned investments for the acquisition of collections, deterioration of infrastructures, lack of preventive and corrective maintenance of the public libraries, obsolescence of computer equipment, obsolescence of collections, lack of resources for the paper edition and dissemination of technical documents for librarians, difficulties for compiling statistics, lack of imported resources and materials which affect the activities of preservation and conservation, lack of capable and specialized professionals, among others [15, 34]. Moreover, the lines of action of recent projects start to contain an ideological charge, by talking of concepts such as the First Socialist Plan.

Most of the challenges academic libraries and the NLAILS are reporting and facing are related to financial issues, which are aggravated by the currency control. The main problematic for libraries is that very few of the resources they must acquire are currently manufactured or sold within the country. Hence, the resources that can be imported imply extra charges over the product's cost, which are derived from the currency control itself, the speculation of costs, and disproportionate import duties and taxes from the State. This situation in further complicated for public libraries, from the NLAILS to the smallest ones, because budget allocations are marginal. The currency control and the scarce financial resources are part of a vicious circle, because with the limited budgets libraries can acquire less resources every year due to the fluctuation of exchange rates, together with inflation, speculation, and State taxes that do not forgive even books. 


\section{Legal issues}

NLAILS' administrative activities face different lingering challenges; the majority of them are caused by budget insufficiency, which raises some doubts about the legal bases supporting our libraries, the convenience of institutionalism, centralization, decentralization or administrative de-concentration. Libraries' public service character is mandated by the Constitution of the Bolivarian Republic of Venezuela (CBRV) [35], but the question is: how we can socially transform libraries in order to fulfill this constitutional mandate that would be their raison d'être. Article 108 is the only part of the CBRV where the word 'library' appears, it states:

Media, both public and private, must contribute to citizen formation. The State will guarantee public services of radio, television and library and computer networks, with the purpose of allowing universal access to information. Educational centers must incorporate the knowledge and application of new technologies, their innovations, according to the requirements established by law (p. 23) [35].

Apart from the first and only NLAILS Law [8], other two legal instruments have supported libraries: a) Legal Deposit Law of 1993, which compels the editorial sector to send a copy of all publications produced in the country to the NL; and b) Organic Municipal Regime Law of 1989, which mandated the existence of municipal PL according to the amount of inhabitants or population, but such disposition is nowhere to be found in the new Organic Public Municipal Power Law of 2010, which replaced the previously mentioned legislation. CERLALC points out that Venezuela does not offer data regarding reading and library indicators (p. 5) [36], specifically the number of PL for every 100,000 inhabitants. This is due in part to the elimination from the current legislation of the requirement of offering municipal library services. However, recently the NLAILS Press Department declared that a new NL Law is being drafted, announcing the 'discussion' of a project. It draws attention the fact that this notice seems to be a reaction in front of the controversial Organic Culture Law, approved in august 2013 and also that the promoters of the so-called 'library constituent' are conducting the 'debate and analysis' of the future legal text behind closed doors, when what would be required is a broad, open, diverse and inclusive consultation, which is characteristic of the participative democracy advocated by the CBRV [35]. This consultation should count not only with working groups in the NL, but it should also take into account what the traditional library schools might have to say, as well as the professional associations (despite their dispersion), the national library workers, cultural promoters, and citizens.

\section{VI.Conclusion}

This is the moment to vindicate Venezuelan libraries, to restore their fundamental value and teach their usefulness to the nation's development. Information professionals and librarians have the responsibility of demonstrating the vital importance of libraries to political leaders, and to make sure their constitutional provision is assumed on the basis of human rights. National library schools must include in their curricular design a much broader and less rigid social vision of libraries, which allow for the identification of the professional role in front of society and diverse communities. Research and comparative librarianship are essential to entrepreneurship, innovation, and competitiveness in a world that is increasingly an Information Society.

Venezuela faces one of the most difficult times of its history. Libraries as institutions and librarianship as profession are instruments for social change and the strengthening of democracy. It is fundamental, now more than ever, to make Venezuelans understand that without information, education and culture there would never be a 'powerful country', much less a 'motherland'. Before extracting all oil reserves, we must learn to read, to think in a free, critical and selective way. Moreover, we have to see our fellowmen as just one more person in the construction of great deeds and not as an adversary that must be ignored because of their political affiliation or their ideology. Finally, before building bridges, highways, schools, hospitals, or even large libraries, first we must build citizenship together. Being citizens is what will open us the way toward development.

\section{References}

[1] Pérez, O.A. Bibliotecas. In: Diccionario de Historia de Venezuela, 2nd Ed.; Fundación Polar: Caracas, Venezuela, 1997; 441-8.

[2] Himiob, S. Historia de la Biblioteca Nacional de Venezuela; Instituto Autónomo Biblioteca Nacional y de Servicios de Bibliotecas: Caracas, Venezuela, 2008 ; 1-180.

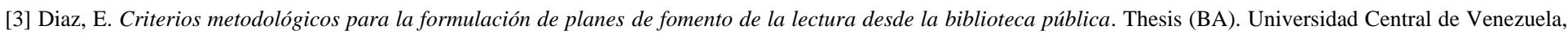
2007; $1-161$.

[4] Alvarado, A. La función social de la biblioteca pública vista a través de cuatro expertos. Thesis (BA). Universidad Central de Venezuela, 2008.

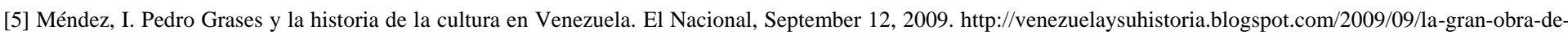
don-pedro-grases.html (accessed January 2015).

[6] Aizpúrua, J. Rómulo Betancourt, padre de la democracia venezolana. [Audiobook] Sophia Producciones: Caracas, Venezuela, 2011.

[7] Ulacio, S. Hay que erradicar la represión salvaje. Versión Final, September 27 2009, 6. 
[8] Congreso de la República de Venezuela. Ley del Instituto Autónomo Biblioteca Nacional y de Servicios de Bibliotecas, Gaceta Oficial Nro. 31284 ; Congreso Nacional: Caracas, 1977; 235799-806. http://www.pgr.gob.ve/dmdocuments/1977/31284.pdf (accessed January 2015).

[9] Flores, C.; Gómez, R.; Soto, M. Legislación de bibliotecas públicas de América Latina: Análisis comparativo. In XVI Conferencia Internacional de Bibliotecología, Santiago, November 2-3, 2011. http://eprints.rclis.org/17502/ (accessed January 2015).

[10] Rodríguez, G. La biblioteca pública: análisis a manifiestos y directrices; Fondo Editorial COMFENALCO: Antioquia, Colombia, 2007 ; 1-68.

[11] Herrera, L. Decreto $\mathrm{N}^{\circ} 1.564$ - 22 de julio de 1982, Gaceta Oficial No 32.522; Procuraduría General de la República: Caracas, 1982 ; $245823-7$. http://www.pgr.gob.ve/dmdocuments/1982/32522.pdf (accessed January 2015).

[12] Córdoba, S. La cooperación regional para el desarrollo social, cultural y bibliotecario. In 60th IFLA General Conference, Havana, August 21-7, 1994. http://www.ifla.org/IV/ifla60/60-cors.htm (accessed January 2015).

[13] UNESCO; CERLALC; IFLA; IABNSB. Declaración de Caracas. En Reunión Regional sobre el Estado Actual y las Estrategias para el Desarrollo de los Servicios de Bibliotecas Públicas en América Latina y el Caribe, Informe Final, Caracas, October 25-29, 1982, 12-7. http://unesdoc.unesco.org/images/0005/000525/052531sb.pdf (accessed January 2015).

[14] Jaramillo, O.; Álvarez, D.; Moncada, D. Políticas públicas para bibliotecas públicas: Una propuesta de soluciones locales a problemas globales. Investigación Bibliotecológica 2005, 19 (39). http://www.ejournal.unam.mx/ibi/vol19-39/IBIO3902.pdf (accessed January 2015).

[15] Guzmán, C. Anuario estadístico cultural, 1990-2003: Las cifras del libro y las bibliotecas en Venezuela; Fundación Polar: Caracas, Venezuela, $2004 ; 1$-203.

[16] ROARMAP. About the repository [Universidad de los Andes]. 2009. http://roarmap.eprints.org/631/ (accessed January 2015).

[17] Redalyc. Red de Revistas Científicas de América Latina y el Caribe, España y Portugal. 2014. http://www.redalyc.org/home.oa (accessed January 2015).

[18] Instituto Nacional de Estadística. Censo de población y vivienda 2001, cuadros estadísticos, Vol. I; INE: Caracas, 2005; 1-489.

[19] Mastromatteo, E. Una anécdota. In Nihiloteca, 2010. http://nihiloteca.blogspot.com/2010_07_01_archive.html (accessed January 2015).

[20] Vicentelli, H. Formación del bibliotecario y archivólogo en Venezuela. Transinformação 1989, 1 (2), 187-94.

[21] Mastromatteo, E. Bases, fundamentos y perfil profesional: Aporte para el cambio curricular de la EBA-UCV. Thesis (MSc). Universidad Central de Venezuela, 2005; 1-182. http://eprints.rclis.org/7672/ (accessed January 2015).

[22] Pirela, J. Desarrollo curricular de la Escuela de Bibliotecología y Archivología de la Universidad del Zulia. In V Encuentro de Educadores e Investigadores de Bibliotecología, Archivología y Ciencia de la Información de Iberoamérica y el Caribe, Maracaibo, 1998.

[23] Pirela, J.; Portillo, L. La evaluación de planes de estudio en Bibliotecología, Archivología y Ciencia de la Información: Enfoques y metodologías. Revista de Artes y Humanidades UNICA 2009, 10 (3), 256-74.

[24] Pirela, J.; Peña, T. La formación del profesional de la información en Venezuela: Una mirada comparativa desde sus diseños curriculares. Educere 2006, 10 (32), 1318.

[25] Pirela, J.; Portillo, L. Construyendo el perfil por competencias del profesional de la información a partir de un dialogo permanente con la sociedad. In IV Encontro Ibérico EDIBCIC, Coimbra, November 18-20, 2009. http://eprints.rclis.org/23020/ (accessed January 2015).

[26] Montilla, L.; Pérez, G. Ciencias de la Información: Formación, retos y nueva propuesta desde Venezuela. Biblios 2012, 46, 33-9.

[27]Ministerio de Educación, Cultura y Deportes. Plan Nacional de Lectura (2002-2012): Todos por la lectura; El Ministerio: Caracas, $2002 ; 6$.

[28] CENAL (2012). Estudio del Comportamiento Lector, Acceso al Libro y la Lectura en Venezuela; Centro Nacional del Libro: Caracas, 2012 ; 1-118. http://www.distribuidoradellibro.gob.ve/ESTUDIO-CENAL-COMPORTAMIENTO-LECTOR.pdf (accessed January 2015).

[29] Ministerio del Poder Popular para la Cultura. Memorias y cuentas del Ministerio del Poder Popular para la Cultura; El Ministerio: Caracas, 2013.

[30] Agencia Venezolana de Noticias. Gobierno venezolano ha invertido $\$ 772$ mil millones en área social, April, 2012. http://www.avn.info.ve/contenido/gobiernobolivariano-ha-invertido-772-mil-millones-\%C3\%A1rea-social (accessed January 2015).

[31] Petróleos de Venezuela. Informe de Gestión Anual 2012; PDVSA: Caracas, 2012; 1-174. http://www.pdvsa.com/interface.sp/database/fichero/free/8010/1625.PDF (accessed January 2015).

[32] Yapur, N. Manejo discrecional de renta petrolera impide atender demanda de divisas. El Nacional, February 16, 2014. http://www.el-nacional.com/economia/divisasalcanzan-manejo-renta-petrolera_0_355764629.html (accessed January 2015).

[33] Aponte, C. El gasto público social durante los períodos presidenciales de Hugo Chávez: 1999-2009. Cuadernos del CENDES 2010, 27 (73), $31-70$. http://www.scielo.org.ve/pdf/cdc/v27n73/art03.pdf (accessed January 2015).

[34] Ministerio del Poder Popular para la Cultura. Memorias y cuentas del Ministerio del Poder Popular para la Cultura; El Ministerio: Caracas, 2006; 2007; 2008; 2009; 2010; 2011; 2012; 2013.

[35] Asamblea Nacional de la República Bolivariana de Venezuela. Constitución Nacional de la República Bolivariana de Venezuela, Gaceta Oficial Extraordinaria ${ }^{\circ}$ 5.453; Asamblea Nacional: Caracas, 1999; 1-45. http://www.tsj.gov.ve/legislacion/GO-24032000-5453.pdf (accessed June 2014).

[36] CERLALC-UNESCO. El libro en cifras. Boletín estadístico del libro en Iberoamérica 2012, 1 (1), 1-16. http://cerlalc.org/wp-content/uploads/2013/03/LEC_I_Def.pdf (accessed January 2015). 